\title{
An Analysis of Teacher and Student Conversation in EFL Classroom Interaction by Using Foreign Language Interaction Analysis System in Class XI at SMK Negeri 1 Singaraja Academic Year 2017/2018
}

\section{Dewi, A.N.P 1}

${ }^{1}$ Universitas Pendidikan Gaensha, Singaraja, Indonesia

A R T I C L E IN F O

Article history:

Available online on

February, 20 2018

Keywords:

FLINT,

Students' talk,

Teacher's talk.

\begin{abstract}
A B S T R A C T
This study aimed at 1) find out classroom interaction categories by using FLINT that exist during English teaching learning process in class XI at SMK N 1 Singaraja using FLINT system. 2) Identifying categories of classroom interaction by using FLINT which are the most and least frequently occurs during the teaching-learning process in class XI at SMK Negeri1 Singaraja 3) discovering the reasons of the interaction during the teaching-learning process in class XI at SMK Negeri 1 Singaraja. This research was a descriptive study by using qualitative approach. There was one class as a sample for this research. The data were collected based on the instruments such as research observation, interview guide, video camera and note-taking. The results of the study show that, 1) two categories of foreign language interaction (FLINT) analysis system all categories of FLINT are occurred during learning process in XI B in SMK N 1 Singaraja, 2) The most frequently occurred of interaction category during three times observation was 'ask question' category.it appeared 121 times in the first meeting, 72 times in the second meeting, and 60 times in the third meeting. The total frequency of asking question was 253 or $24,5 \% 3$ ) the reason of the occurrence of 'ask question' category is the difficulty of the students in learning and the students need teacher's guidance.
\end{abstract}

Copyright (C) Universitas Pendidikan Ganesha. All rights reserved. 


\section{Introduction}

Teacher and students need to interact regularly using the target language since interaction is the heart of communication in order to get experience in English communication (Brown, 2001:165). Interaction occurs as long as people are communicating each other and giving action and receiving the reaction in one another anywhere and anytime, including in the classroom setting. Dagarin (2004: 128) argued that classroom interaction is "two-way process between the participants in the language process, the teacher influences the learners. Richard (1992) stated that, classroom interaction is the pattern of verbal and non-verbal communication and the types of social relationship which occur within classroom. Through meaningful interaction, the English teacher can provide opportunity for the learner interaction when they are in a group or individual work. Moreover, classroom interaction can stimulate the student to speak because it is useful in stimulating the student to think, understand and gives respond to the given stimulation.

Unfortunately, participant during interactions in the language classroom seem difficult to use the target language all the time,especially in the EFL (English as a Foreign Language) classroom. It happened since the EFL students have common native languages (Brown, 2001:180). If the teacher of EFL ignores it, the goal of teaching process could not be achieved.

Based on the preliminary observation, in a class of SMA N 4 Singaraja and a class of students in SMK N 1 Singaraja which had been observed last August 2017 it was found that teacher were difficult to create a balanced classroom interaction since they used a foreign language to interact, especially in using English. For example if the teacher dominated the classroom because the students donot really understand how to use the language and they became not active in responding the teacher's talk or question.

The problem related to the interaction using native language in English speaking classroom can be solved if teacher and learner realize the important of interaction in language classroom. Rivers (1987:4) stated that interaction play significant roles in the language classroom since it can increase students' language store. For those interaction in the language classroom have advantages to the students speaking performance, therefore the study about classroom interaction is considerably important and worth to be analysed.

XI B class of SMK N 1 Singaraja is one class which have problem in the classroom interaction. There are three classes of this second grade of tourism senior high school and the researcher chooses XI B class because this is one of the excellent classes of three classes. By the result of preliminary observation which have been done, it was observed that the students who were expected to learn and active more in the classroom were just sitting in silence. There were few students who participate actively in answering the teacher questions meanwhile some of them responded the teacher's talk inappropriately, like shouting.

FLINT is a concept which states that teaching will be effective depends to a large degree on how directly and indirectly teachers influence the learners' behaviour. Brown (2001:177) stated that this model is helpful in developing interactive language teaching. First, it gives you taxonomy for observing other teachers. Second, it gives you a framework for evaluating and improving your own teaching, such as how well do you balance teacher talk and student talk. Third, the FLINT model, especially the first seven categories, helps to set a learning climate for interactive teaching.

Since FLINT system used to analyze classroom which deals with foreign language, the researcher isinterested to conduct the classroom analysis in SMK Negeri1 Singaraja by using FLINT System as measurement. SMK Negeri1 Singaraja is selected because this school is one category of good school in the mastery of English. As the result of primarily observation eleventh grade is selected because this grade suitable to be investigated or observed.

\section{Methods}

This research is a descriptive study by using qualitative approach. A descriptive study is chosen because this study will describe situation or phenomena, in this case is teacher-students classroom interaction at the eleventh grade of SMK Negeri1 Singaraja. This theory based on Hancock (2002) which explained that qualitative research is a research of describes social phenomena which happen naturally. The definition by Hancock (2002) is also supported by the definition about qualitative research by Denzin and Lincoln (2010:16) state that qualitative research is a research which uses natural background in order to interpret a phenomena happened. It involves several method of data collection such as, interview and observation.

In this descriptive study by using qualitative approach, observation need as the technique which gathered the data in the form of observing the subject of this study. Simply, observation is identified as the 
process of observing, watching, noticing, and listening carefully any particular information from the participants (Langley, 1988). In qualitative research, there two type of observation, they are direct observation and participant observation (Trochim, 2006).

Direct observation is defined as the observation which is done by watching and observing without any interaction as the participant in the context, therefore this type of observation is more focused on the object of study rather than trying to enter the context. However, participant observation is the researcher trying to be participant in context, enter the context and collect any data needed. Unfortunately, this participant observation need longer time than direct observation because the researcher needs to be natural part of the culture and context (Trochim, 2006).

The interview is given to the teacher by asking some questions arranged. It is done to find out the purpose of doing the interaction. The researcher interview both students and the teacher. The students that will be interview. Interview guide will be used to help the researcher in asking some question of interview to the students. It will be done to confirm the reason of using such classroom interaction by using foreign language interaction analysis system. The interview guide will be asking about the interaction in the classroom based on FLINT that occurs in the classroom. The question derive from the theory of Brown (2001) is an interaction analysis which is able to be applied for classroom observation. Based on the statement this interview will be about the teacher interaction in the classroom.

Data analysis is part of doing research. After getting the research analyze the data in order to get the result of the findings. After finding the data, researcher will draw the conclusion of the study. In this study, the researcher used Miles and Huberman data analysis theory in 1984. This is the process of data analysis:

Miles and Huberman Data Analysis (1984)

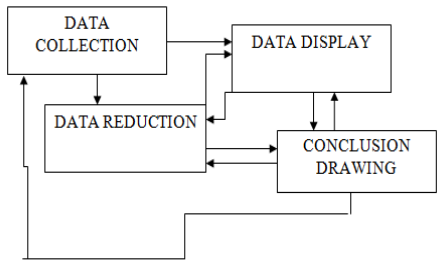

Figure 1.

Miles and Huberman Data Analysis

In this study, the researcher needed to do a data reduction to get a selective data which is useful in this study. The activities in data reduction include selecting, simplifying, classifying, categorizing and coding data (Miles and Huberman, 1984 as cited by Seken, 2004). Any data which is not suitable with the category would be ignored. . In this step researcher sorted, chose, and classified the findings into some types which are appropriate to answer the research problem. The findings were sorted, classified, and chosen according to the theories.

In this study, the data would be displayed in the form of written data. There was no number and statistical analysis. The data was displayed descriptively and in the form of table.

In this study, the data would be verified by relating the finding with the literature review. In other word, researcher sorted, chose, and classified the findings into some types which are appropriate to answer the research problem. The findings were sorted, classified, and chosen according to the theories. After that, the data would be concluded to answer the statement of the problem.

In any types of research, the trustworthiness of research is important to be achieved to ensure the validity a reliability of research data. Trustworthiness used by the researcher was triangulation. Triangulation refers to the use of more than one approach to the investigation of a research question in order to enhance confidence in the ensuring findings (Bryman, 2003, p. 1142). Triangulation means the researcher observe to find data that can support he study, the use the researcher perception to analyze the data according the theories. And the researcher compares the result of researcher's perception with the subject's perception according the interview result. From those, the researcher found whether the researcher perception which was conducted according to the theories and previous studies about politeness same as the findings in her study. Type of triangulation as follow:

1. Methodological Triangulation

This type of triangulation was used in this research means that the researcher used more than one procedure of data collection. The aim of using this type triangulation is to gather more valid data.

2. Data Triangulation 
Data triangulation means that the researcher collected the data in my sources including time, space, and persons/people. This type of triangulation helped the researcher to avoid any weakness of data collection.

\section{Findings and Discussion}

FLINT has twenty two categories. The analysis of each category consisted of one or more examples of utterances that randomly chosen during the observation in SMK Negeri 1 Singaraja, in class XI.

The first category in FLINT was 'deals with feelings'. This category means the ways of teacher deals with student's feeling by saying particular utterances which are evidence into some categories, accepting, discussing, ignoring, refreshing to, or communicating understanding of past, present, and future feeling of the student. Feeling may be positive or negative. Predicting or feelings are included. From the analysis, this category occurred 39 utterances or 3,8\% from three times observation

The second category is 'praises or encourages'. This category refers to the teacher praises or encourages students' involvement or behavior. It shows that the words are approval of admiration for somebody or something toward students' positive contribution. Encouragement is the act of encouraging somebody to perform the knowledge. This can be informed or praising, complimenting, and trying to give them confidence, and confirming answer are correct. From the analysis, this category occurred $5,4 \%$ with 56 utterances from three times observations.

'Jokes' is the next category, based on FLINT system, 'jokes' refers to teacher's utterances that made student laugh. Making joke is one of ways to initiate interaction and release tension. However, teacher has considered that his jokes should never annoy others' feeling. The data analysis shows that this category 1 times or $0,1 \%$ during the three times observation.

The next category of FLINT was 'uses ideas of students'. 'Uses ideas of students' mean that the teacher clarifies, interprets, summarizes, or paraphrases students' idea. In the observation, this category occurred 16 times or $1,5 \%$ in percentages.

'Repeat students response verbatim' is the part of the previous category of FLINT. In this category, the teacher would repeat the students' exact words after they participated in the interaction. This category occurred 41 times or 3,0\% in percentages.

The next category in FLINT was 'asks questions'. 'Ask questions' means that the teacher delivers questions to the students. Teacher frequently asks questions in the classroom to which they already know the answer (display question) rather than those they do (referential question). Based on the acquired data, this category appeared 253 times or $24,5 \%$.

'Give information' refers to the teacher's effort into deliver some information to students related to the lesson that were being taught. It is commonly employed by the teacher during teaching and learning process. In this study, giving information involves, facts, opinions about content or procedure, expressing own ideas, lecturing, giving own explanations, or citing an authority other that student. From the analysis, this category occurred 70 times or $6,8 \%$ from three time observations.

The next category from FLINT was 'corrects without rejection'. This category refers to the utterances which indicate that the teacher corrects the students' response without using words or intonation which communication criticism. 'Corrects without rejection' aimed at making the students aware of making mistake. From the observation, there are 26 times of this category or 2,5\% in percentages.

'Give direction' was the next category of FLINT. This category refers to entire teacher's utterances, commands, orders, or directions that require students' compliance. Through the direction given by their teacher, the students are expected to understand what they supposed to do during teaching and learning process. According to the data analysis, this category occurs 102 times or $9,9 \%$ in percentages.

'Direct pattern drills' refers to giving statements which students are expected to repeat exactly, to make substitution, or to change from one to another. From the analysis, this category occurred 63 times or $6,1 \%$.

The next category was 'criticizes student behavior'. This category referred to utterance of rejecting students' behavior, trying to change the non-acceptable behavior, communicating anger, displeasure, annoyance, and dissatisfaction of what the students are doing during the teaching and learning process. This category amed at avoiding obstacle in the lesson so what was planned by the teacher could run smoothly.

'Criticizes student, response' refer to the teacher tells the student that his/her response is not correct or acceptable and communicating criticism, pleasure, annoyance, rejection by words or intonation. From the analysis, this category occurred 15 times or $1,4 \%$ in percentages. 
'Student response-specific' was one of FLINT category. This category refers to the student's response which involves previously practiced answer or dictation drills. This category occurred 106 times or about $10,2 \%$.

'Student response-choral' this category indicated with student talk in respond the teacher by the total class or part of the class. This response usually occurs because the teacher gives question or command spread to all students not specific student. From the analysis, this category occurred 56 times or $5,4 \%$ in percentages.

The next category was 'student response, open-ended or student-initiated'. This kind of response referred to the students' own ideas, opinion, reactions, or feelings toward something which were initiated by the students themselves. There were 38 utterances or about or 3,5\% in total.

Next category from FLINT system was 'silence'. 'Silence' refers to a period of quiet during which no verbal interaction occurred between the teacher and the student. The pauses interaction happened during several conditions in the classroom. Based on the data analysis, the silence occurs 36 times and the percentage is $3,5 \%$. There were several reasons of why this category could be appeared, those are:

1. The teacher asked something to the student but they took too much time to answer.

2. Teacher gave the student an opportunity to think of the answer of a certain question.

3. The students wrote down something on the white board.

4. The students had group activity or do the task from their book.

'Silence-AV' is also one of the categories in FLINT. This category is different from the 'silence' category. 'Silence-AV' means the period of no verbal interaction because the teacher prepares audio-visual equipment, such as: video, tape recorder, LCD projector,etc. The equipment would be used to support the lesson. this category never occurred during the teaching learning process.

The next category was 'confusion, work-oriented'. Confusion means that the interaction cannot be recorded because more than one person is talking. This confusion could be detected when the students were calling out excitedly, eager participate, and concerned with the task at the hand. In all the observations, 'confusion, work-oriented' occurred 5 times or $0,5 \%$ in percentage. It appeared when the students discussed about the answer of certain question, took turn in questioning and answering section.

The other category was 'confusion, non-work-oriented'. This is the second kind of confusion. It referred to a situation where more than one person was talking and the students were out of order, not concerned with the task at hand, and not behaved as the teacher expected. This kind of confusion often occurred when the students waited for other students who had not finished their work or when a student come forward to the class to wrote down the answer. The data obtained showed that 'confusion, nonwork-oriented' occurred 2 times or $0,2 \%$ during the observation.

For the next category was 'laughter'. 'Laughter' means laughing by the class, individuals, and or the teacher. The data showed that 'laughter' happened 2 times or $0,2 \%$. This category happened because the teacher gave the students some jokes or when students answered the question mistakenly.

'Uses of native language' also was one of several categories of FLINT. The native language here was Indonesian language. The teacher also used it in teaching the students. It was helpful to make the students understand about what was spoken by the teacher. The 'uses of native language' could be only a word in one sentence or one sentence in whole. This category occurred 79 times or 7,6\%.

The last category of FLINT was 'nonverbal. 'Nonverbal referred to the use of gesture instead of verbal language. This category occurred when the teacher gave certain code to the students in order to make them listen, behave in appropriate way, or give permission to the students by nodding. 'Nonverbal' occurred 11 times or $1,1 \%$.

Based on the result, overall twenty two categories of foreign language interaction (FLINT) analysis system all categories of FLINT are occurred during learning process in XI B in SMK N 1 Singaraja, especially for the 'teacher talk' which still dominated in the classroom.

The data above shows that most frequently occurred of interaction category during three times observation was 'ask question' category, the total frequency of asking question was 253 or $24,5 \%$, as the category of FLINT analysis system was less frequently occurred was 'silence-AV'. It not happened in three times observations. It can be assumed that the teacher is still primarily needed in the classroom to control the student's learning and the student needs more engaging activity.

All FLINT categories are already occurred in the classroom in terms of student's talk and teacher's talk. Based on the phenomena that occurred in the classroom interaction, by interviewing the teacher, the reason of this phenomenon happened because of kinds of material taught by the teacher because to explain the material is quite difficult so the teacher needs to focus with student understanding 


\section{Conclusion} follows.

Based on finding and discussion in the previous chapter, the present study can be concluded as

a. FLINT system involves 22 categories. During the observation in SMK Negeri 1 Singaraja, especially in XI B class. All of FLINT categories occurred in the classroom. They appeared in variant frequency a percentage. The category of teacher talk that occurred mostly was 'asks question'. This refers to teacher's behaviour in asking question to the student, in order to make the student remember and understand about the material have been taught. Because all categories of FLINT are occurred during teacher and student interaction during learning process, it can be assumed that there is an indication that FLINT is needed to enhance learning process in SMK N 1 Singaraja.

b. The most frequently occurred of interaction category during three times observation was 'ask question' category.it appeared 121 times in the first meeting, 72 times in the second meeting, and 60 times in the third meeting. The total frequency of asking question was 253 or $24,5 \%$. Where as the category of FLINT analysis system was less frequently occurred was 'silence-AV'. It not happened in three times observations.

c. By conducting an interview with the teacher and students, the most and the least of FLINT category which frequently occurred, the reason of the category of 'asks question' which mostly appeared was that the teacher aimed at checking students understanding, prior knowledge and also rechecking students memorization about the certain topic. By asking question, the students can prepare themselves to improve their knowledge. While, the least category which frequently occurred was 'silence-AV. It happenned because during the teaching and learning process teacher not used media to teach. The teacher said that if using the media is easier, but the current material is quite difficult and if the teacher using the media will be more difficult. Furthermore it is not appropriate with the material taught.

\section{References}

Brown, H. D. (2004). Language Assesement : Principles and Classroom Practices. USA:Longman.

Brown, H. D. (2001). Teaching by Principle.San Francisco:Longman.

Creswell.,\&John W. Planning. Education Research: Conducting and Evaluating Quantitative and Qualitative Research. Universitas Nebraska-Lincolyn.

Chaudron, C. (1984). The Effects of Feedback on Students' Composition Revisions. RELCJournal, 15(2),114. http://dx.doi.org/10.1177/003368828401500201

Dagarin, M (2004). Classroom Interaction and Communication Strategies in Learning English as a Foreign. Ljubljana: Biorografika Bori Ljunljana.

Denzin\&LIncoln.(2005). Handbook of qualitative research.Sage.

Moskowitz. G (1972) Interaction Analysis Gives Insight into Student-Teacher Exchanges. Foreign Language Bacon, Vol. 7,10-13.

Miles, M. B., Huberman, A. M., \& Saldaña, J. (n.d.). Qualitative data analysis : a methods sourcebook.

Richards, J. (1992). Second Language Teacher Education.Cambridge: Cambrigde University Press.

Rivers, W. M. (1987). Interactive Language Teaching. Cambridge: Cambridge University Press.

Trochim.,

\&William,

M.K.

(2006)Likert

Scaling.Social

Research http://www.socialresearch.net/kb/order.php 